\title{
Polymorphisms of Pro-Inflammatory IL-6 and IL-1 $\beta$ Cytokines in Ascending Aortic Aneurysms as Genetic Modifiers and Predictive and Prognostic Biomarkers
}

\author{
Letizia Scola ${ }^{1}$, Rosa Maria Giarratana ${ }^{1}$, Vincenzo Marinello ${ }^{2}$, Valeria Cancila ${ }^{3}$, Calogera Pisano ${ }^{4}$, \\ Giovanni Ruvolo ${ }^{4}$, Giacomo Frati ${ }^{5,6}$, Domenico Lio ${ }^{1, *(1)}$ and Carmela Rita Balistreri ${ }^{1}$ ([)
}

check for updates

Citation: Scola, L.; Giarratana, R.M.; Marinello, V.; Cancila, V.; Pisano, C.; Ruvolo, G.; Frati, G.; Lio, D.; Balistreri, C.R. Polymorphisms of Pro-Inflammatory IL-6 and IL-1 $\beta$ Cytokines in Ascending Aortic Aneurysms as Genetic Modifiers and Predictive and Prognostic Biomarkers Biomolecules 2021, 11, 943. https:// doi.org/10.3390/biom11070943

Academic Editor: Chris T. Amemiya

Received: 11 May 2021

Accepted: 22 June 2021

Published: 25 June 2021

Publisher's Note: MDPI stays neutral with regard to jurisdictional claims in published maps and institutional affiliations.

Copyright: () 2021 by the authors Licensee MDPI, Basel, Switzerland. This article is an open access article distributed under the terms and conditions of the Creative Commons Attribution (CC BY) license (https:/ / creativecommons.org/licenses/by/ $4.0 /)$.
1 Clinical Pathology, Department of Bio-Medicine, Neuroscience, and Advanced Diagnostics, University of Palermo, 90100 Palermo, Italy; letizia.scola@unipa.it (L.S.); rosamaria.giarratana@unipa.it (R.M.G.); carmelarita.balistreri@unipa.it (C.R.B.)

2 Department of Legal and Economic Sciences, University of Enna "Kore", 94100 Enna, Italy; vincenzo.marinello@unikore.it

3 Tumor Immunology Unit, Department PROMISE, University of Palermo, 90100 Palermo, Italy; valeria.cancila@unipa.it

4 Department of Cardiac Surgery, University of Rome 'Tor Vergata', 00100 Rome, Italy; calogera.pisano@uniroma2.it (C.P.); giovanni.ruvolo@uniroma2.it (G.R.)

5 Department of Medical-Surgical Sciences and Biotechnologies, Sapienza University of Rome, 04100 Latina, Italy; giacomo.frati@uniroma1.it

6 IRCCS NEUROMED, 86077 Pozzilli, Italy

* Correspondence: domenico.lio@unipa.it

\begin{abstract}
Background: Previous studies have demonstrated that polymorphisms involved in immune genes can affect the risk, pathogenesis, and outcome of thoracic ascending aortic aneurysms (TAAA). Here, we explored the potential associations of five functional promoter polymorphisms in interleukin6 (IL-6), IL-1B, IL-1A, IL-18, and Tumor necrosis factor (TNF)A genes with TAAA. Methods: 144 TAAA patients and 150 age/gender matched controls were typed using KASPar assays. Effects on telomere length and levels of TAAA related histopathological and serological markers were analyzed. Results: Significant associations with TAAA risk were obtained for $I L-6$ rs1800795G $>C$ and $I L-1 B$ rs16944C > T SNPs. In addition, the combined rs1800795C/rs16944T genotype showed a synergic effect on TAAA pathogenesis and outcome. The combined rs1800795C/rs16944T genotype was significantly associated with: (a) higher serum levels of both cytokines and MMP-9 and -2; (b) a significant CD3+CD4+CD8+ CD68+CD20+ cell infiltration in aorta aneurysm tissues; (c) a significant shorter telomere length and alterations in telomerase activity. Finally, it significantly correlated with TAAA aorta tissue alterations, including elastic fragmentation, medial cell apoptosis, cystic medial changes, and MMP-9 levels. Conclusions: the combined rs1800795C/rs16944T genotype appears to modulate TAAA risk, pathogenesis, and outcome, and consequently can represent a potential predictive and prognostic TAAA biomarker for individual management, implementation of innovative treatments, and selection of the more proper surgical timing and approaches.
\end{abstract}

Keywords: thoracic ascending aortic aneurysms; proinflammatory cytokines; rs1800795; rs16944; telomere length; MMP9; elastic fragmentation; medial cell apoptosis; cystic medial changes

\section{Introduction}

In recent decades, inflammation has been demonstrated to have a crucial role in cardiovascular diseases (CVD) [1,2], characterized by high worldwide morbidity and mortality. Accordingly, inflammation evocates endothelial dysfunction, the primum movens of many CVD, from the atherosclerosis [3,4] and its complications (i.e., myocardial infarction, coronary artery disease, ischemic stroke, peripheral arterial occlusive disease, and heart failure [2,4-6]), to other cardiovascular pathological conditions [7]. In addition, individuals affected by chronic inflammatory disorders (i.e., autoimmune disorders) 
show a significant increase in the cardiovascular susceptibility. [6] Many inflammatory pathways have been documented to contribute to CVD onset and progression, including TLR-4/NF-k $\beta$ pathway [8,9], TLR-2 [10], TGF- $\beta 1$ [11], CCR5 [12], CRP [13]. Recently, pro- and anti-inflammatory cytokines, such as interleukin-(IL)-10 [14] and IL-6 [15], have been associated with CVD onset and progression, and current meta-analyses [16-19] have also confirmed the relationship of some functional polymorphisms in pro-inflammatory cytokine genes with the significant increase in the susceptibility to several CVD, abdominal aortic aneurysms included. Consistent with this, a prospective multicenter observational open-label cohort study of patients, the MA3RS study [20], has demonstrated the importance of monitoring aortic wall inflammation via ultrasmall superparamagnetic particles of iron oxide-enhanced magnetic resonance imaging for significantly predicting both the rate of aneurysm growth, and the risk of severe complications, such as aneurysm rupture [20].

These interesting data have prompted evaluation of the contribution of inflammatory pathways and cytokines to risk and pathogenesis of sporadic thoracic ascending aortic aneurysms (TAAA). Our group has recently demonstrated the crucial role of TLR-4/NF-k $\beta$ and TGF- $\beta$ in the risk and progression of TAAA and type A dissection and evidenced genetic variants in their genes as important risk determinants of these diseases $[8,9,21-23]$. The group of researchers involved in Genetically Triggered Thoracic Aortic Conditions (GenTAC) registry study, has also found a significant association between the high systemic levels of $I L-6$ and aortic dimensions in patients with aortopathies [24]. Another group has assessed an overexpression of $I L-1 \beta$ in patients with TAAA [25]. In this view, the identification of genetic, epigenetic and circulating biomarkers might be of help for update the current TAAA guidelines on the surgical timing, which is the key for positively influencing the survival of affected patients and is based exclusively on aorta diameter [22]. A growing body of evidence indicates that a biological and morphological network of risk factors might be considered and aortic ruptures and dissections might also take place in ascending aortas having smaller sizes than those recommended by the current guidelines [22] (Figure 1).

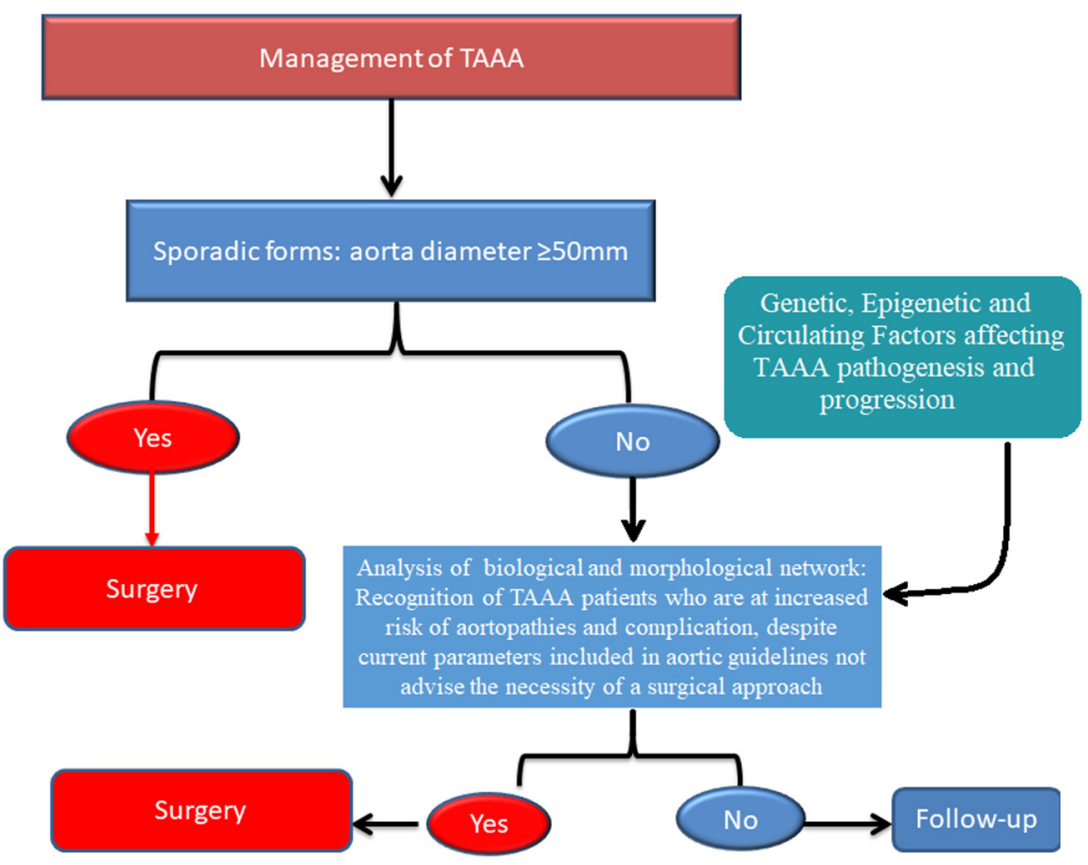

Figure 1. Management of patients with TAAA (Flow Chart). This algorithm was proposed to include biological and morphological network of genetic, epigenetic and circulating markers useful for updating current guidelines on the TAAA management behind the aortic diameter [22].

In line with these recent data, and for validating the associations previously observed [22], here, we aimed to investigate the potential association of functional polymorphisms in IL-6, IL-1A, IL-1B, IL-18, and Tumor necrosis factor (TNF)A genes with TAAA 
susceptibility, pathogenesis, and outcome, in 144 patients affected by sporadic TAAA and 150 age/gender matched controls. Five functional promoter polymorphisms in the genes encoding for $I L-6, I L-1 \alpha, I L-1 \beta, I L-18$ and TNF- $\alpha$ pro-inflammatory cytokines, known to be functionally important, because they influence both the transcription rate of the related genes and cytokine plasma concentrations, have been selected [26-30]. In addition, we evaluated the eventual genotypes of these gene variants able to influence in a significant manner the systemic levels of the analyzed cytokines and other inflammatory markers (i.e., proteases), as well as the amounts of tissue infiltrated CD3+CD4+CD8+CD68+CD20+ immune/inflammatory cells. Correlations of the polymorphisms (i.e., their genotypes) with molecular and cellular aorta wall impairment, leukocyte telomere length attrition and telomerase activity alterations, able to suggest the rate of tissue biological aging, tissue chronic inflammation, related damage, and the resulting aorta remodeling/degeneration, reflecting the aneurysm growth and/or rupture, were also estimated.

\section{Materials and Methods}

\subsection{Patients and Controls}

Our study included a population of 144 subjects with TAAA (101 men and 43 women; mean age: $70.3 \pm 2.6$ years) and 150 age/gender matched healthy subjects (100 men and 50 women; mean age: $69.5 \pm 1.6$ years), as shown in Table 1 . Patients were recruited from February 2017 to December 2017, in the Units of Cardiac Surgery and Cardiology (Department of Cardiac Surgery, University of Rome 'Tor Vergata', Rome, Italy). Exclusion criteria [31-34]: (a) cardiovascular diseases; (b) genetic, familial and sporadic connective tissue disorders; (c) congenital aorta valve diseases, such as bicuspid valve syndrome; (d) infectious and inflammatory diseases. A total of 150 healthy age and gender matched controls were recruited after clinical and laboratory evaluation.

Table 1. Demographic and clinical characteristics of population enrolled.

\begin{tabular}{cccc}
\hline Variables & TAAA Cases & Controls & $\boldsymbol{p}^{\mathbf{1}}$ \\
\hline Demographic characteristics & $n=144$ & $n=150$ & \\
Age, mean (SD) & $70.3(2.6)$ & & \\
Male sex, No. (\%) & $101(70.1)$ & $100(66.6)$ & n.s. \\
Female sex, No. (\%) & $43(29.9)$ & $50(33.4)$ & n.s. \\
Body mass index, mean (SD) & $25(4.3)$ & $24.8(3.1)$ & n.s. \\
\hline Size and location of TAAA & & & \\
Size (mm), mean (DS) & $52.6(7.1)$ & - & - \\
Localization N. (\%): Tubular & $144(100)$ & - & n.s. \\
ascending aorta & & & n.s. \\
\hline Comorbidity conditions, No (\%) & $18(12.5)$ & $10(6.7)$ & 0.03 \\
CVD Family History & $50(34.7)$ & $50(33.4)$ & 0.05 \\
Smoking & $75(52)$ & $60(40)$ & n.s. \\
Hypertension & $22(15.3)$ & $12(8)$ & n.s. \\
Dyslipidemia & $13(9)$ & $8(5.3)$ & n.s. \\
Diabetes mellitus & $0(0)$ & $0(0)$ & n.s. \\
Renal failure & $0(0)$ & $0(0)$ & $0(0)$ \\
Dissection & $2(0)$ & &
\end{tabular}

${ }^{1} p$ was determined by $t$ test for quantitative variables, or Pearson $\chi^{2}$ test for qualitative variables.

Table 1 reports clinical and demographic data (including comorbidities) obtained from patients' medical records. 


\subsection{DNA Samples and Genotyping}

DNA samples from patients and controls, extracted from peripheral blood and purified by using QIAamp Blood DNA Maxi kit (Qiagen, Dusseldorf, Germany), were typed for five polymorphisms located in the promoter region of the five selected candidate genes codifying pro-inflammatory cytokine reported in Table 2.

Table 2. Genes and SNPs (accession number from https://www.ncbi.nlm.nih.gov/snp/?term, accessed on 21 April 2021) investigated in the study [24-28].

\begin{tabular}{cccccc}
\hline Genes & SNPs & $\begin{array}{c}\text { Chr } \\
\text { Localization }\end{array}$ & Position & Alleles & $\begin{array}{c}\text { Biological } \\
\text { Effects }\end{array}$ \\
\hline IL-1A & rs1800587 & $2: 112785383$ & -889 & $\mathrm{C}>\mathrm{T}$ & $\begin{array}{c}\text { Increased levels of } \\
\text { gene transcription }\end{array}$ \\
IL-1B & rs16944 & $2: 112837290$ & -511 & $\mathrm{C}>\mathrm{T}$ & $\begin{array}{l}\text { Increased levels of } \\
\text { genenscription } \\
\text { Variable levels of }\end{array}$ \\
IL-6 & $\mathrm{rs} 1800795$ & $7: 22727026$ & -174 & $\mathrm{G}>\mathrm{C}$ & $\begin{array}{l}\text { gene transcription } \\
\text { Increased levels of }\end{array}$ \\
IL-18 & $\mathrm{rs} 187238$ & $11: 112164265$ & -137 & $\mathrm{G}>\mathrm{C}$ & $\begin{array}{l}\text { gene transcription } \\
\text { Increased levels of }\end{array}$ \\
TNFA & $\mathrm{rs} 1800629$ & $22: 23894205$ & -308 & $\mathrm{G}>\mathrm{A}$ & gene transcription \\
\hline
\end{tabular}

The allelic and genotypic frequencies of these gene variants were detected using Kaspar assay on demand developed by KBioscience Ltd. (KBioscience, Middlesex, UK) and based on a homogeneous Fluorescence Resonance Energy Transfer (FRET) detection and allele specific PCR routinely used in our laboratory [21].

\subsection{Quantifications of Systemic Levels of IL-1 $\beta, I L-6, M M P-9$ and $M M P-2$}

Plasma levels of inflammatory cytokines (IL-1 $\beta$, and -6), and MMP-9 and -2 were measured by ELISA and commercial kits (R\&D Systems, Minneapolis, MN, USA), according to the manufacturer's instructions. Detection limits were $0.7 \mathrm{pg} / \mathrm{mL}, 0.5 \mathrm{pg} / \mathrm{mL}, 0.154 \mathrm{ng} / \mathrm{mL}$, $0.156 \mathrm{ng} / \mathrm{mL}$ for $I L-1 \beta, I L-6, M M P-9$ and -2 , respectively. All assays were run in duplicate.

\subsection{Aortic Specimens and Histopathological Assays and Apoptosis Evaluation}

Full aortic segments with resected normal as well as aneurysmatic aortic wall from tubular-ascending aorta were collected from all patients with TAAA. They were microscopically examined, after staining (hematoxylin-eosin, Weigert, van Gieson and Alcian-PAS staining, see Figures S1 and S2 in Supplementary Materials) according to the 2016 consensus criteria for aorta histology [35].

We also assessed apoptosis by perform TdT (Terminal deoxynucleotidyl Transferase)mediated X-dUTP (deoxyuridine triphosphate nucleotides) nick end-labeling (TUNEL) reaction (Roche Diagnostics S.p.A, Milano, Italy) on deparaffined sections of full-thickness aortic wall $(5 \mu \mathrm{m})$, as previously described [31-34,36].

\subsection{Immunohistochemical Assays}

Immunohistochemical analyses were performed on $5 \mu \mathrm{m}$-thick paraffin-embedded sections incubated for $1 \mathrm{~h}$ with appropriate dilutions of specific monoclonal antibodies (Ab)s against CD3 (Clone LN10, NCL-L-CD3, clone PS1, Novocastra Laboratories Ltd., Newcastle upon Tyne, UK, 1:100), CD45 (Santa Cruz, Biotechnology, Inc, Santa Cruz, CA, USA, 1:100), CD4 Ab-2 (Clone 1 F6, NeoMarkers, Inc, Fremont, CA, USA, 1:10), CD8 Ab-1 (Clone C8/144B, NCL-L-CD8 295 mouse Novocastra Laboratories Ldt, Newcastle upon Tyne, UK, 1:50), CD20 (clone L 26, Dako Italia Spa, Milan, Italy, 1:50)), CD68 (clone PG-M1, Dako Italia SpA, Milan, Italy, 1:50), MMP-9 (Clone 15W2, NCL-MMP9 439, Novocastra Laboratories Ltd., Newcastle upon Tyne, UK, 1:50), or isotype-matched controls. After washing in TBS 1X (Tris-buffered solution), staining was performed by biotinylated an- 
tibodies and streptavidin labeled with peroxidase (Dako, North America, Inc, Via Real Carpinteria, CA, USA) and was detected using 3-amino-9-ethylcarbazole substrate (AEC). Counterstaining of cells and tissue sections was performed using aqueous hematoxylin (Novocastra Laboratories Ldt, Newcastle upon Tyne, UK). Inflammatory and immune cells were counted in 10 contiguous high-power fields (magnification $400 \times$ ) under an Olympus fluorescent microscope (Olympus America Inc, Center Valley, PA, USA) by two independent observers.

\subsection{Semi-Quantitative Evaluation of MMP-9 by Immunohistochemical Assays}

A semi-quantitative evaluation of MMP-9 amount in aortic specimens was performed. Staining was classified as low, moderate, or high amount (see Figure S2).

\subsection{Telomere Length Assay and Telomerase Activity Evaluation}

The mean terminal restriction fragment (TRF) length, was detected by chemiluminescence technique and using the TeloTAGGG telomere length assay kit (Roche Diagnostics, Indianapolis, IN, USA), according to the manufacturer's instructions. The mean terminal restriction fragment (TRF) was calculated applying the following formula: TRF = $\left(\sum(\mathrm{ODD})\right) /\left(\sum(i \mathrm{OD} / L i)\right)$, based on measurement of is the optical density at a given position on the gel $\left(\mathrm{OD}_{i}\right)$ and the position corresponding molecular weight $\left(L_{i}\right)$. As previously described [36], the mean TRF of electrophoresis runs from cases and controls were adjusted to the standardized internal control.

For quantitative analysis of telomerase activity, a Telomeric Repeat Amplification Protocol (TRAP) [36] and a photometric enzyme immunoassay were performed using TeloTAGGG Telomerase PCR Elisa Plus kit (Roche Diagnostics, Indianapolis, IN, USA), according to the manufacture's protocol [36].

\subsection{Statistical Analysis}

Significant differences in frequencies between the two groups were calculated using the $\chi 2$ test and appropriate tables $(2 \times 2,3 \times 2)$. Unpaired $t$-test (Welch corrected) was utilized to analyze the quantitative data between two groups whereas one-way ANOVA or Kruskal-Wallis test followed by Bonferroni correction was applied to compare more than two groups. The correlations between two continuous variables were assessed with Pearson's test, or non-parametrical Spearman correlation test. Multiple logistic regression analyses of dominant and recessive models were applied to patient group compared with control group. Odds ratios (OR), 95\% confidence intervals (95\% C.I.), and $p$ values were determined. SPSS software version 20 (SPSS Inc., Chicago, IL, USA) was used. Differences were considered significant when a $p$ value $<0.05$ was obtained by comparison between the different groups.

\section{Results}

3.1. Frequencies and Associations of Cytokine Functional Promoter Polymorphisms with TAAA Risk in Enrolled Groups

Genotype frequencies of all studied population fit to Hardy-Weinberg equilibrium. The comparison of genotype distributions and allele frequencies between cases and controls allows to detected only significant differences both in genotype distributions and allele frequencies of the rs.16944 IL-1B and rs.1800795 IL-6 gene variants, between the cases and the matched controls (Table 3).

In particular, we observed that the TAAA cases showed a significant frequency $(0.153$ vs. 0.02 and $p<0.00009 ; 0.152$ vs. 0.034 and $p<0.0015$, by Chi-square test) of TT and CC genotypes, respectively of the rs.16944 IL-1 $\beta$ and rs.1800795 IL-6 gene variants than the controls. Analogously, the frequency of T and C alleles, respectively of the rs.16944 IL-1 $\beta$ and rs. 1800795 IL-6 gene variants, was significantly higher in cases than controls ( $0.236 \mathrm{vs}$. 0.087 and $p<0.000001 ; 0.222$ vs. 0.100 , and $p<0.00008$ by Chi-square test). 
Table 3. Genotype distributions and allele frequencies of gene variants (SNPs) typed in case and control groups. All genotypes were in Hardy-Weinberg equilibrium.

\begin{tabular}{|c|c|c|c|c|c|c|c|c|c|c|c|c|c|}
\hline \multirow{5}{*}{$\begin{array}{c}\text { Candidate } \\
\text { Gene }\end{array}$} & \multirow{3}{*}{$\begin{array}{c}\text { SNP Reference } \\
\text { Number }\end{array}$} & \multicolumn{4}{|c|}{ Alleles } & \multirow[t]{3}{*}{$\begin{array}{c}p \text { Value } * \\
(2 \times 2 \text { Table })\end{array}$} & \multicolumn{6}{|c|}{ Genotypes } & \multirow[t]{3}{*}{$\begin{array}{c}p \text { Value } * \\
(3 \times 2 \text { Table })\end{array}$} \\
\hline & & \multicolumn{2}{|c|}{$\mathrm{C}$} & \multicolumn{2}{|c|}{$\mathrm{T}$} & & \multicolumn{2}{|c|}{$\mathrm{CC}$} & \multicolumn{2}{|c|}{$\mathrm{CT}$} & \multicolumn{2}{|c|}{ TT } & \\
\hline & & $\mathrm{N}$ & $\mathrm{F}$ & $\mathrm{N}$ & F & & $\mathrm{N}$ & $\mathrm{F}$ & $\mathrm{N}$ & $\mathrm{F}$ & $\mathrm{N}$ & $\mathrm{F}$ & \\
\hline & Cases & 193 & 0.670 & 95 & 0.330 & \multirow[b]{2}{*}{ n.s. } & 61 & 0.424 & 70 & 0.486 & 13 & 0.090 & \multirow[b]{2}{*}{ n.s. } \\
\hline & Controls & 209 & 0.697 & 91 & 0.303 & & 72 & 0.480 & 65 & 0.433 & 13 & 0.087 & \\
\hline \multirow{3}{*}{$I L-1 B$} & rs16944 & \multicolumn{2}{|c|}{$\mathrm{C}$} & \multicolumn{2}{|c|}{$\mathrm{T}$} & & \multicolumn{2}{|c|}{$\mathrm{CC}$} & \multicolumn{2}{|c|}{$\mathrm{CT}$} & \multicolumn{2}{|c|}{ TT } & \\
\hline & $(-511 C>T)$ & $\mathrm{N}$ & $\mathrm{F}$ & $\mathrm{N}$ & F & & $\mathrm{N}$ & $\mathrm{F}$ & $\mathrm{N}$ & $\mathrm{F}$ & $\mathrm{N}$ & $\mathrm{F}$ & \\
\hline & Controls & 274 & 0.913 & 26 & 0.087 & 0.000001 & 127 & 0.847 & 20 & 0.133 & 3 & 0.02 & 0.00009 \\
\hline \multirow{4}{*}{$I L-6$} & rs1800795 & \multicolumn{2}{|c|}{ G } & \multicolumn{2}{|c|}{$\mathrm{C}$} & & \multicolumn{2}{|c|}{ GG } & \multicolumn{2}{|c|}{ GC } & \multicolumn{2}{|c|}{$\mathrm{CC}$} & \\
\hline & $(-174 G>C)$ & $\mathrm{N}$ & $\mathrm{F}$ & $\mathrm{N}$ & F & & $\mathrm{N}$ & $\mathrm{F}$ & $\mathrm{N}$ & $\mathrm{F}$ & $\mathrm{N}$ & $\mathrm{F}$ & \\
\hline & Cases & 224 & 0.778 & 64 & 0.222 & & 102 & 0.708 & 20 & 0.140 & 22 & 0.152 & \\
\hline & Controls & 270 & 0.900 & 30 & 0.100 & 0.00008 & 125 & 0.833 & 20 & 0.133 & 5 & 0.034 & 0.0015 \\
\hline \multirow{3}{*}{$I L-18$} & rs187238 & \multicolumn{2}{|c|}{ G } & \multicolumn{2}{|c|}{$\mathrm{C}$} & & \multicolumn{2}{|c|}{ GG } & \multicolumn{2}{|c|}{ GC } & \multicolumn{2}{|c|}{ CC } & \\
\hline & $(-137 G / C)$ & $\mathrm{N}$ & $\mathrm{F}$ & $\mathrm{N}$ & F & & $\mathrm{N}$ & $\mathrm{F}$ & $\mathrm{N}$ & $\mathrm{F}$ & $\mathrm{N}$ & $\mathrm{F}$ & \\
\hline & Controls & 219 & 0.730 & 81 & 0.270 & n.s. & 82 & 0.547 & 55 & 0.367 & 13 & 0.087 & n.s. \\
\hline \multirow{4}{*}{ TNFA } & rs1800629 & & & & & & & & & & & & \\
\hline & $(-308 \mathrm{G} / \mathrm{A})$ & $\mathrm{N}$ & $\mathrm{F}$ & $\mathrm{N}$ & F & & $\mathrm{N}$ & $\mathrm{F}$ & $\mathrm{N}$ & $\mathrm{F}$ & $\mathrm{N}$ & $\mathrm{F}$ & \\
\hline & Cases & 251 & 0.872 & 37 & 0.128 & & 112 & 0.777 & 27 & 0.188 & 5 & 0.035 & \\
\hline & Controls & 270 & 0.900 & 30 & 0.100 & n.s. & 124 & 0.827 & 22 & 0.147 & 4 & 0.026 & n.s. \\
\hline
\end{tabular}

$\mathrm{N}=$ number; $\mathrm{F}=$ frequency (genotype distribution and allele frequencies). ${ }^{*} p$ value was calculated by using $\chi 2$ test and appropriate $3 \times 2$ and $2 \times 2$ tables. 
Furthermore, the logistic regression analyses of dominant and recessive models performed between TAAA cases and controls showed a significant enrichment of the recessive genotypes of two polymorphisms in cases respect to controls, associated with significant risk TAAA values (Table 4 ).

Table 4. Multiple logistic regression analyses of dominant and recessive models applied to patient group compared with control group.

\begin{tabular}{|c|c|c|c|c|}
\hline SNP & Model & Numbers & OR (95\% C.I.) & $p$ Values * \\
\hline \multirow{2}{*}{$\begin{array}{c}\text { rs16944 } \\
(-511 C>T)\end{array}$} & $\begin{array}{c}\text { Dominant } \\
\mathrm{CC}+\mathrm{CT} / \mathrm{TT}\end{array}$ & $\begin{array}{l}\text { Cases: } 122 / 22 \\
\text { Controls: } 147 / 3\end{array}$ & $0.11(0.03-0.38)$ & $<0.00001$ \\
\hline & $\begin{array}{c}\text { Recessive } \\
\mathrm{CT}+\mathrm{TT} / \mathrm{CC}\end{array}$ & $\begin{array}{c}\text { Cases: } 46 / 98 \\
\text { Controls: } 23 / 127\end{array}$ & $2.59(1.47-4.56)$ & 0.0006 \\
\hline \multirow{2}{*}{$\begin{array}{l}\text { rs1800795 } \\
(-174 G>C)\end{array}$} & $\begin{array}{c}\text { Dominant } \\
\mathrm{GG}+\mathrm{GC} / \mathrm{CC}\end{array}$ & $\begin{array}{l}\text { Cases: } 122 / 22 \\
\text { Controls: } 145 / 5\end{array}$ & $0.21(0.07-0.57)$ & 0.0008 \\
\hline & $\begin{array}{c}\text { Recessive } \\
\mathrm{CC}+\mathrm{GC} / \mathrm{GG}\end{array}$ & $\begin{array}{c}\text { Controls: } 25 / 125 \\
\text { Cases: } 42 / 102\end{array}$ & $2.05(1.17-3.06)$ & 0.0077 \\
\hline
\end{tabular}

${ }^{*} p$ value was calculated by using $\chi 2$ test and appropriate $3 \times 2$ and $2 \times 2$ tables; OR was calculated with Fisher's exact test.

\subsection{Higher Systemic Plasma Levels of Inflammatory Systemic Molecules and Aorta Tissue} Immune/Inflammatory Cells in Cases with the Combined -511T IL-1B/-174C IL-6 Genotype than Controls Bearing the Same Genotype

The significant enrichment in the frequencies of rs.16944 IL-1B and rs.1800795 IL-6 gene variants in TAAA cases than controls and the high OR values of recessive genotypes in the cases led us to suppose that these polymorphisms might have the role of genetic modifiers, promoting TAAA pathogenesis and outcome. Consequently, we examined the biological effects mediated by the rs.16944 IL-1B and rs. $1800795 \mathrm{IL}-6$ gene variants in cases and controls bearer or not of $-511 T I L-1 B /-174 C$ IL-6 combined genotypes, by quantifying both the amount of aorta tissue cellular infiltration of CD3+CD4+CD8+CD68+CD20+ inflammatory immune cells (Figure 2) and the plasma levels of the two $I L-1 \beta$ and $I L-6$ cytokines and metalloproteinases (MMP)-2 and -9 (Table 5).
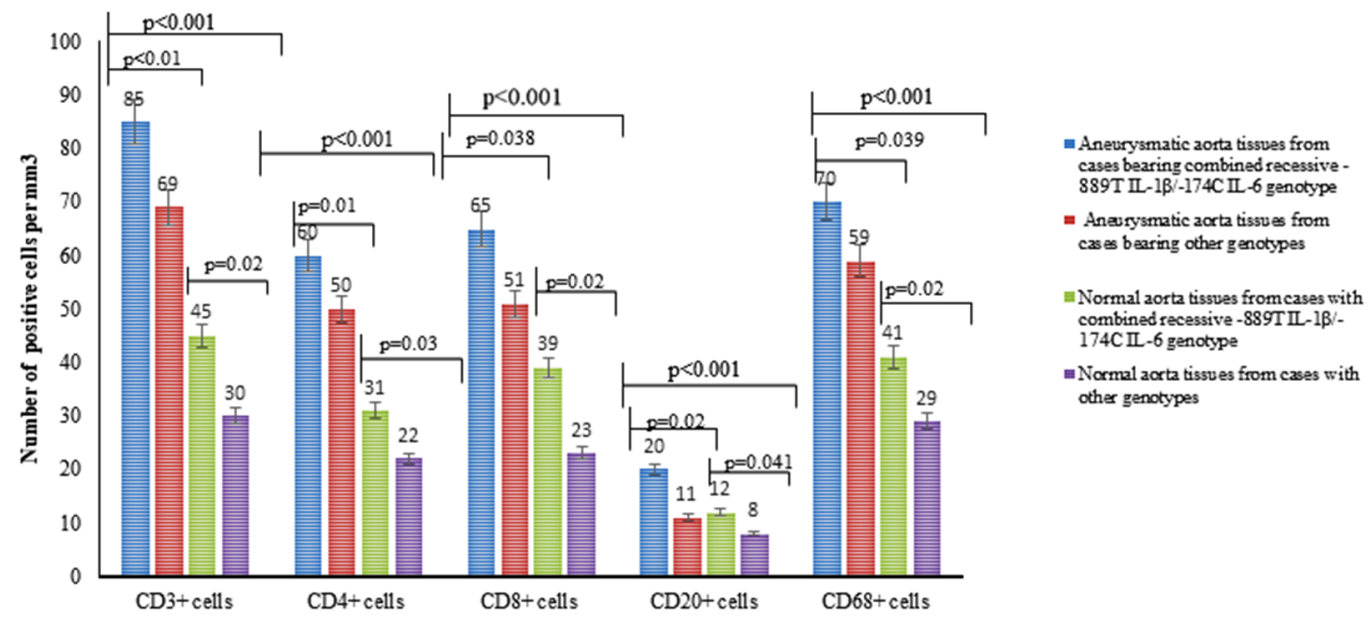
cases bearing combined recessive $=$ Aneurysmatic aorta tissves from cases bearing other genotypes $\equiv$ Normal aorta tissves from cases with combined recessive -889TIL-1B/174 CII-6 genotype $=$ Normal aorta tissues from cases with other genotypes

Figure 2. Immunohystochemical quantification of lymphocytes, $\mathrm{T}$ cell subpopulations, and macrophages in aorta samples (aneurysmal and normal areas) from cases with combined -511T IL-1B/-174C IL-6 genotype vs. cases with other genotypes. CD3, CD4, CD8, CD20, and CD68 positive cells in media and adventitia and in 10 contiguous high-power fields (magnification $400 \times$ ) were counted by two independent observers. Significant increased amounts of CD3+CD4+CD8+CD68+CD20+ cells were observed by comparing their values (medium values $\pm \mathrm{SD}$ ) among the four groups and the two groups (by ANOVA and $t$ test). Surprisingly, cases with the combined genotype had higher numbers of these cells than cases with other genotypes, in both aneurysmatic and normal aorta tissue areas. 


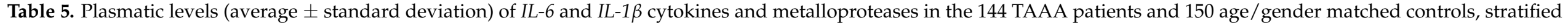
according the presence of combined recessive (-511T IL-1B/-174C IL-6) genotype.

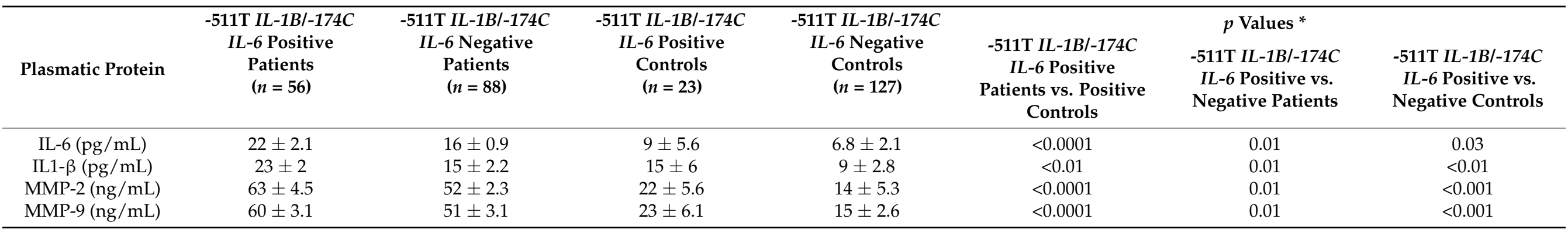

* $p$ was determined by $\mathrm{t}$ test with Welch correction. 
The comparisons effectuated between the cases and controls bearer or not of $-511 T$ $I L-1 B /-174 C$ IL-6 combined genotypes demonstrated that the cases positive for combined genotype had significantly higher levels of systemic inflammatory cytokines and proteases than the controls with the same genotype or carriers of other genotypes (Table 5). Besides, cases carrying $-511 T$ IL-1 $\beta /-174 C$ IL-6 genotype had significantly higher amount of tissue CD3+CD4+CD8+CD68+CD20+ inflammatory immune cells both in normal and aneurysmatic aorta tissues (Figure 2).

Overall, these results also led us to suppose that the rs.16944 IL-1B and rs.1800795 IL-6 gene variants might also be considered not only genetic modifiers of TAAA pathogenesis, but also potential predictive and prognostic TAAA biomarkers because they correlated with the raise and grade of both systemic and tissue chronic inflammation, remodeling and degeneration when they are both present.

3.3. A Significant Impairment of the Leukocyte Telomere Length and Telomerase Activity in Cases with Combined the -511T IL-1B/-174C IL-6 Genotype than Controls

To assess the predictive and prognostic risk effects of combined -511 T IL-1B/-174C IL-6 genotype in cases than controls, we evaluated the eventual telomere/telomerase system's impairment, it being the gold standard biomarker for evaluation of the grade of biological aging of all the tissues. As widely reported in our recent work [36] and documented in the literature (see the relevant data of Wilson and colleagues, [37]), it reflects in an exact manner both the grade of chronic inflammation and remodeling/degeneration of all the body tissues, or, better, the biological age of all the tissues.

Therefore, we examined the mean of blood leukocyte telomere length and telomerase activity, using terminal restriction fragment assay (TRF test,), and a relative quantitative analysis in according to Telomeric Repeat Amplification Protocol (TRAP).

As reported in Table 6, we have detected a significant impairment of telomere/telomerase leukocyte system in TAAA cases with combined recessive -511T IL-1B/-174C IL-6 genotype than controls with the same genotype. In addition, controls positive for the combined genotype had impairment of telomere/telomerase leukocyte system than other control individuals, carriers of another genotype. This finding might suggest that the combined recessive $-511 T$ $I L-1 B /-174 C$ IL-6 genotype is associated with a significant risk of early biological aging of cardiovascular system, and consequently to develop an early aorta remodeling and degeneration, that might evolve in TAAA onset.

Table 6. Mean TRF length, mean values of relative telomerase activity (RTA), in leukocytes from patients and controls positive or negative for combined genotype ${ }^{1}$.

\begin{tabular}{|c|c|c|c|c|c|c|c|c|}
\hline Evaluations & $\begin{array}{c}\text { Case's Carriers } \\
\quad(n=56)\end{array}$ & $\begin{array}{l}\text { Control's } \\
\text { Carriers } \\
(n=23)\end{array}$ & $\begin{array}{l}\text { Cases with } \\
\text { Other } \\
\text { Genotypes } \\
(n=88)\end{array}$ & $\begin{array}{c}\text { Controls } \\
\text { with Other } \\
\text { Genotypes } \\
(n=127)\end{array}$ & $\begin{array}{c}p 1^{*} \\
\text { Values }\end{array}$ & $\begin{array}{c}p 2^{* *} \\
\text { Values }\end{array}$ & $\begin{array}{l}p 3^{* * *} \\
\text { Values }\end{array}$ & $\begin{array}{l}p 4^{* * * *} \\
\text { Values }\end{array}$ \\
\hline Mean TRF length & $4899 \pm 0.569 b p$ & $\begin{array}{c}6588 \pm 0.449 \\
\text { bp }\end{array}$ & $\begin{array}{l}5680 \pm \\
0.176 \mathrm{bp}\end{array}$ & $\begin{array}{c}7500 \pm \\
0.656 \mathrm{bp}\end{array}$ & $<0.001$ & $<0.0001$ & 0.01 & $<0.0001$ \\
\hline Mean RTA values & $12.6 \pm 3.2$ & $60.8 \pm 5.6$ & $27 \pm 3.3$ & $75 \pm 6.2$ & $<0.0001$ & $<0.0001$ & 0.001 & $<0.0001$ \\
\hline
\end{tabular}

1. unpaired $\mathrm{t}$ test with Welch correction was used for statistical analyses. Data are reported as mean \pm standard deviation. ${ }^{*} p 1$ values obtained comparing patients with combined genotype vs. controls with combined genotype; ${ }^{* *} p 2$ values obtained comparing patients with combined genotype vs. controls with other genotypes; ${ }^{* * *} p 3$ values obtained comparing patients with combined genotype vs. patients with other genotypes; ${ }^{* * * *} p 4$ values obtained comparing controls with combined genotype vs. controls with other genotypes.

3.4. Univariate Analysis of Combined -511T IL-1B/-174C IL-6 Genotype with Increase in MMP9 Amount, Elastic Fragmentation, Medial Cell Apoptosis, Cystic Medial Changes in Hystological Speciments

To test whether the combined $-511 T$ IL-1 /-174C IL-6 genotype correlated with aorta tissue remodeling/degeneration, elastic fragmentation, tissue aorta MMP-9 amount, medial cell apoptosis, cystic medial changes in TAAA cases were detected and a univariate regression analysis was applied. As reported in Table 7, a significant correlation was 
detected between the combined genotype and aorta alterations, including an increased MMP-9 amount, elastic fragmentation, medial cell apoptosis and cystic medial changes. Besides, it significantly correlated with the augment of aorta diameter $(\mathrm{r}=0.15$ and $p=0.01$, by linear Pearson correlation test; data not shown) in the cases bearer.

Table 7. Univariate correlations between elevation of MMP9 amount, elastic fragmentation, medial cell apoptosis, cystic medial changes, and the combined recessive (-511T IL-1B/-174C IL-6) genotype in cases.

\begin{tabular}{ccc}
\hline Variables & r Values & $p$ Values * \\
\hline Elastic fragmentation & 0.21 & 0.001 \\
Elevation of MMP 9 amount & 0.17 & 0.02 \\
Medial cell apoptosis & 0.16 & 0.001 \\
Cystic medial changes & 0.18 & 0.04 \\
\hline * linear Pearson correlation test, or non-parametric Spearman correlation test, when appropriate.
\end{tabular}

\section{Discussion}

Inflammation plays a crucial role in the CVD development and progression. Accordingly, our and other groups have demonstrated significant associations between many inflammatory pathways, and mediators, and TAAA [8,9,21-25]. Pro-inflammatory cytokines, and particularly IL-6, have been shown to represent significant drivers of CVD [38,39], aneurysms included. Its crucial role in CVD has been proven by prospective studies, demonstrating how high basal plasmatic levels of IL-6, having pro-inflammatory and procoagulant effects, are potent CVD risk factors [40-43]. In addition, other pieces of evidence arrive from the significant results of a recent meta-analysis of 74 studies, showing a significant association of the $-174 \mathrm{C}$ allele (rs1800795) of $I L-6$ gene polymorphism with several CVD, including myocardial infarction, coronary artery disease, ischemic stroke, peripheral arterial occlusive disease, and heart failure [16], in spite of functional effect of this allele on IL-6 serum level [44]. Recent studies have also confirmed its role in abdominal aortic aneurysms [42,43], Here, we demonstrated the role of $I L-6$ and $I L-1 B$ in TAAA disease. Precisely, we evidenced that the functional $-174 \mathrm{G}>\mathrm{C}$ ( $\mathrm{rs} 1800795)$ and $-511 \mathrm{C}>\mathrm{T}$ (rs16944) polymorphisms, respectively in $I L-6$ and $I L-1 B$ genes, were significantly associated with TAAA risk. Such gene variants increased the TAAA susceptibility under allelic (C and $\mathrm{T}$, respectively), homozygous (CC and TT) and heterozygous (GC and CT) genotypes. Higher systemic levels of the two cytokines were significantly assessed in plasma samples of cases bearing such gene variants than controls, and particularly when carriers of combined recessive -511T IL-1B/-174C IL-6 genotype. Likewise, cases with the combined recessive -511TIL-1B/-174C IL-6 genotype showed higher systemic plasma levels of MMP-9 and-2 respect to controls. This appears to suggest that the two polymorphisms induce a higher systemic inflammatory pressure, that might likely result in a more marked cytokineinduced aorta remodeling and degeneration. Accordingly, we detected in aorta tissues from the cases with combined recessive -511T IL-1B/-174C IL-6 genotype, and particularly in aneurisma vs. normal regions, a significant immune/inflammatory cellular infiltration. Aneurisma tissues are characterized by the presence not only of a significant number of CD68+ monocyte/macrophage cells, but also by a high quantity of the T CD4+ and CD8+ cells followed by a reduced number of B lymphocytes with the typical CD20+ marker. Generally, their presence indicates a chronic inflammation response [45,46]. However, the phenotypes of the T CD4+, CD8+, and B cell subpopulations were not analyzed in our study, as well as gene expression and cytokine production. In fact, it has recently been reported that the cytokines produced by CD4+ and CD8 + T-lymphocytes and their subsets, such as CD248+ CD8+ T cells [47], play a causative role in the initiation and progression, as well as in the suppression, of aorta remodeling associated with onset of pathological conditions, such as aorta dilatation and aneurysm development [46,48]. Of note, for example, is the role of the abovementioned CD248+ CD8 + T [47] cells subset and its cytokine profile, that has been recently demonstrated to suppress the pathological vascular remodeling in 
human TAAA. This underlines the imperative necessity to investigate the type of T subsets in the aneurysm aorta tissues and their cytokine profile.

In this view these results allow to suggest that the rs16944 IL-1B and rs.1800795 IL-6 gene variants might be considered not only genetic modifiers of TAAA pathogenesis, but also potential predictive and prognostic TAAA biomarkers. Consistent with these considerations, the rs16944 IL-1B and rs1800795 IL-6 gene variants correlated with the rise and grade of both systemic and tissue chronic inflammation and biological aging of aorta tissue. Accordingly, cases with the combined -511T IL-1B/-174C IL-6 genotype than control carriers of the same genotype had shorter telomeres and a reduced telomerase activity. Leukocyte telomere length and telomerase activity are strictly associated with the grade of biological aging of body tissues, organs and systems, and reflect both the grade of tissue chronic inflammation and remodeling/degeneration [36,49-51]. The significant associations between the impairment of telomere length and telomerase activity and $174 \mathrm{G}>\mathrm{C}$ (rs1800795) IL-6 and -511C > T (rs16944) IL-1B gene polymorphisms, seem to confirm the contribution of combined genotype in TAA onset and progression and, consequently, it might represent a TAAA predictive and prognostic risk marker. An additional confirmation arrives from the significant correlations between the combined -511T IL-1B/-174C IL-6 genotype and the TAAA tissue aorta typical alterations, including elastic fragmentation, MMP-9 aorta tissue amount, medial cell apoptosis and cystic medial changes.

\section{Conclusions}

Taken together, the results obtained appear to strongly suggest that the two $-174 \mathrm{G}>\mathrm{C}$ (rs1800795) IL-6 and -511C $>\mathrm{T}$ (rs16944) IL-1B gene polymorphisms are genetic risk factors for TAAA, in accordance with the literature data reported on the several CVD, as mentioned above [38-43]. However, to the best of our knowledge, this study represents the first performed in TAAA and, consequently, confirmations on large numbers of individuals enrolled are imperative.

The crucial genetic mechanisms related to higher susceptibility to the same diseases may be realized by different genotypes, which can affect different mediating mechanisms, in populations of different genetic backgrounds [52-54]. In our case, this must be considered in relation to the biological effects mediated by the two $-174 \mathrm{G}>\mathrm{C}$ (rs1800795) IL-6 and $-511 C>T$ (rs16944) IL-1B gene polymorphisms, and particularly by the combined $-511 T$ IL1B/-174C IL-6 genotype that might contribute to the different steps of TAAA pathogenesis and progression (Figure 3). Afterward, we explored this issue considering the ethnicity of our population in study. Being a Caucasian population, the literature data have reported a significant association only under homozygous recessive model (TT and CC) of the polymorphisms examined in our study, and particularly for -174G $>C$ (rs1800795) IL-6 polymorphism [16].

Some limitations also characterize our study. First, we need to consider the sample size. However, the total number of subjects enrolled was relatively small given the incidence and prevalence of TAAA, even if the validation of our data needs to be confirmed in a larger sample of patients and controls. Second, our study was an association analysis that correlated genotype to TAAA risk, cytokine levels and histologic, immune-histochemical, telomere/telomerase markers of arterial wall degeneration, molecular pathways of arterial damages should be further investigated, as well as the tissue molecule expression. Third, the biological effects of the two polymorphisms studied are complex and other genetic variants of their functional pathways might be implied [55]. Consequently, further research is needed to fully understand the contribution of two $-174 \mathrm{G}>\mathrm{C}$ ( $\mathrm{rs} 1800795)$ IL-6 and $-511 \mathrm{C}>\mathrm{T}$ (rs16944) IL-1B gene polymorphisms in TAAA. 


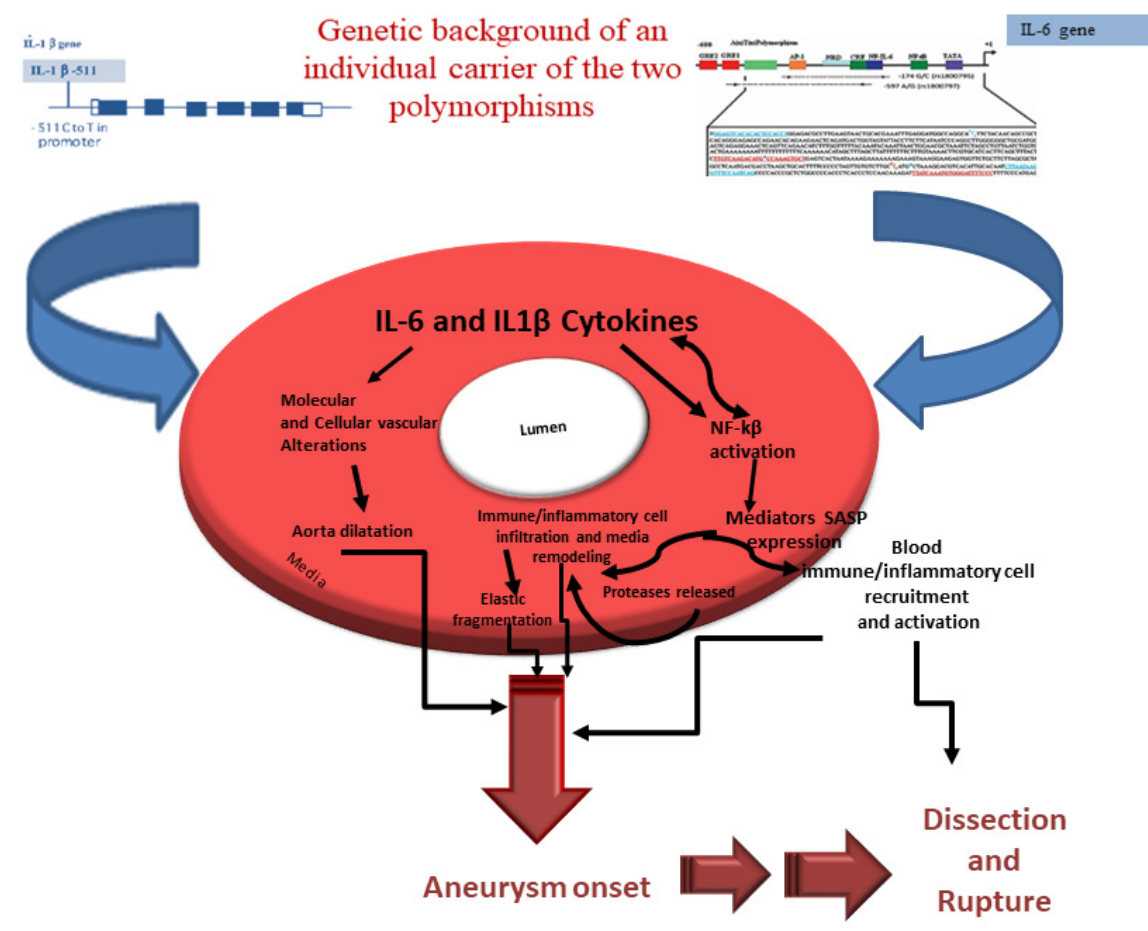

Figure 3. Our model on the role of rs1800795 IL-6 and rs16944 IL-1B gene polymorphisms in TAAA onset. Subjects carrying combined $-511 T$ IL-1B/-174C IL-6 genotype show high significant levels of two related cytokines, known have a key role in the onset and progression of CVD. In the context of TAAA pathogenesis, they mediate cellular and molecular alterations of intima, inducing endothelium dysfunction and, in turn, immune/inflammatory infiltration, and media remodeling/degeneration. Such determines aorta dilation and, consequently, aneurysm onset and its complications, dissection, and rupture.

However, genotyping could consent to identify TAAA risk individuals and might represent a helpful biomarker useful in drive preventive treatments for delaying or stopping onset and progression of TAAA. Specific inhibitors of inflammation (nonsteroidal antiinflammatory drugs or other more sophisticated preventive approaches (i.e., agonists of IL- receptors or anti-IL- 6 or $I L-1 \beta$ antibodies), might be used, as well as more appropriate surgical approaches and decisions in subjects positive for this genotype.

Supplementary Materials: The following are available online at https:/ / www.mdpi.com/article/10 $.3390 /$ biom11070943/s1: Aortic specimens and histopathological assays and apoptosis evaluation, Figure S1: Control aortas and histo-pathological abnormalities in aorta tissues of S-TAA patients; Figure S2: Medial apoptosis and MMP-9 amount in tissue samples.

Author Contributions: Study conception and design: C.R.B., L.S. and D.L. Experiments performed: C.R.B., L.S., R.M.G. and V.C. Acquisition of the results and data analyses: C.R.B. and V.M. Analysis and interpretation of data: C.R.B., L.S., V.C., G.R., G.F., C.P. and D.L. Writing-original draft preparation and drawing figures: C.R.B., L.S. and R.M.G. Study supervision and critical revision: C.R.B. and D.L. All authors have read and agreed to the published version of the manuscript.

Funding: This research was funded by Italian University Minister FFABR grant 2017 to C.R.B. University of Palermo FFR 2019/20 grants to C.R.B. and L.S. Research fund of the Molecular Medicine and Biotechnologies PhD curriculum-XXXIII cycle of Palermo University to R.M.G.

Institutional Review Board Statement: Study was performed in accordance with ethical standards of the Helsinki Declaration of the World Medical Association and Italian legislation, and it received approval from Palermo University Ethics Board (No. APUNIP008213456/2015).

Informed Consent Statement: Informed consent was obtained from all subjects involved in the study. 
Data Availability Statement: All data generated or analyzed during this study are included in this published article.

Acknowledgments: The authors are grateful to team of A. Orlando from the Department of Anatomic Physiology, University of Rome "Tor Vergata", Rome, Italy, and E. Maresi from Anatomic Pathology, University of Palermo, Palermo, Italy, for the histopathological and immunochemistry investigations, and the group of Ruvolo for collecting blood and tissue samples, and demographic and clinical data.

Conflicts of Interest: The authors declare no conflict of interest.

\section{References}

1. Furman, D.; Campisi, J.; Verdin, E.; Carrera-Bastos, P.; Targ, S.; Franceschi, C.; Ferrucci, L.; Gilroy, D.W.; Fasano, A.; Miller, G.W.; et al. Chronic inflammation in the etiology of disease across the life span. Nat. Med. 2019, 25, 1822-1832. [CrossRef]

2. Sorriento, D.; Iaccarino, G. Inflammation and cardiovascular diseases: The most recent findings. Int. J. Mol. Sci. 2019, 20, 3879. [CrossRef]

3. Stojanović, S.D.; Fiedler, J.; Bauersachs, J.; Thum, T.; Sedding, D.G. Senescence-induced inflammation: An important player and key therapeutic target in atherosclerosis. Eur. Heart. J. 2020, 41, 2983-2996. [CrossRef] [PubMed]

4. Castro-Ferreira, R.; Cardoso, R.; Leite-Moreira, A.; Mansilha, A. The role of endothelial dysfunction and inflammation in chronic venous disease. Ann. Vasc. Surg. 2018, 46, 380-393. [CrossRef]

5. Ismaeel, A.; Brumberg, R.S.; Kirk, J.S.; Papoutsi, E.; Farmer, P.J.; Bohannon, W.T.; Smith, R.S.; Eidson, J.L.; Sawicki, I.; Koutakis, P. Oxidative stress and arterial dysfunction in peripheral artery disease. Antioxidants 2018, 7, 145. [CrossRef] [PubMed]

6. Penack, O.; Luft, T. Endothelial dysfunction during inflammation and alloimmunity. Front. Immunol. 2018, 9, 2886. [CrossRef] [PubMed]

7. Pisano, C.; Balistreri, C.R.; Ricasoli, A.; Ruvolo, G. Cardiovascular disease in ageing: An overview on thoracic aortic aneurysm as an emerging inflammatory disease. Mediat. Inflamm. 2017, 2017, 1274034. [CrossRef]

8. Balistreri, C.R. Genetic contribution in sporadic thoracic aortic aneurysm? Emerging evidence of genetic variants related to TLR-4-mediated signaling pathway as risk determinants. Vascul. Pharmacol. 2015, 74, 1-10. [CrossRef] [PubMed]

9. Balistreri, C.R.; Ruvolo, G.; Lio, D.; Madonna, R. Toll-like receptor-4 signaling pathway in aorta aging and diseases: “Its double nature". J. Mol. Cell. Cardiol. 2017, 110, 38-53. [CrossRef] [PubMed]

10. Balistreri, C.R.; Candore, G.; Mirabile, M.; Lio, D.; Caimi, G.; Incalcaterra, E.; Caruso, M.; Hoffmann, E.; Caruso, C. TLR2 and age-related diseases: Potential effects of Arg753Gln and Arg677Trp polymorphisms in acute myocardial infarction. Rejuvenation Res. 2008, 11, 293-296. [CrossRef] [PubMed]

11. Crivello, A.; Giacalone, A.; Scola, L.; Forte, G.I.; Nuzzo, D.; Giacconi, R.; Cipriano, C.; Candore, G.; Mocchegiani, E.; ColonnaRomano, G.; et al. Frequency of polymorphisms of signal peptide of TGF-beta1 and -1082G/A SNP at the promoter region of Il-10 gene in patients with carotid stenosis. Ann. NY Acad. Sci. 2006, 1067, 288-293. [CrossRef] [PubMed]

12. Balistreri, C.R.; Caruso, C.; Grimaldi, M.P.; Listì, F.; Vasto, S.; Orlando, V.; Campagna, A.M.; Lio, D.; Candore, G. CCR5 receptor: Biologic and genetic implications in age-related diseases. Ann. N.Y. Acad. Sci. 2007, 1100, 162-172. [CrossRef]

13. Balistreri, C.R.; Vasto, S.; Listì, F.; Grimaldi, M.P.; Lio, D.; Colonna-Romano, G.; Caruso, M.; Caimi, G.; Hoffmann, E.; Caruso, C.; et al. Association between $+1059 \mathrm{G} / \mathrm{C}$ CRP polymorphism and acute myocardial infarction in a cohort of patients from Sicily: A pilot study. Ann. N.Y. Acad. Sci. 2006, 1067, 276-281. [CrossRef] [PubMed]

14. Lio, D.; Candore, G.; Crivello, A.; Scola, L.; Colonna-Romano, G.; Cavallone, L.; Hoffmann, E.; Caruso, M.; Licastro, F.; Caldarera; et al. Opposite effects of interleukin 10 common gene polymorphisms in cardiovascular diseases and in successful ageing: Genetic background of male centenarians is protective against coronary heart disease. J. Med. Genet. 2004, 41, 790-794. [CrossRef]

15. Chiappelli, M.; Tampieri, C.; Tumini, E.; Porcellini, E.; Caldarera, C.M.; Nanni, S.; Branzi, A.; Lio, D.; Caruso, M.; Hoffmann, E.; et al. Interleukin-6 gene polymorphism is an age-dependent risk factor for myocardial infarction in men. Int. J. Immunogenet. 2005, 32, 349-353. [CrossRef] [PubMed]

16. González-Castro, T.B.; Hernández-Díaz, Y.; Pérez-Hernández, N.; Tovilla-Zárate, C.A.; Juárez-Rojop, I.E.; López-Narvaez, M.L.; Blachman-Braun, R.; Posadas-Sánchez, R.; Vargas-Alarcón, G.; García-Flores, E.; et al. Interleukin 6 (rs1800795) gene polymorphism is associated with cardiovascular diseases: A meta-analysis of 74 studies with 86,229 subjects. EXCLI J. 2019, 18, 331-355. [CrossRef]

17. Zhang, S.; Gao, Y.; Huang, J. Interleukin-8 Gene -251 A/T (rs4073) polymorphism and coronary artery disease risk: A metaanalysis. Med. Sci. Monit. 2019, 25, 1645-1655. [CrossRef]

18. Zhou, L.; Zhu, X.; Wang, J.; Cheng, Y.; Ma, A.; Pan, X. Association between interleukin-18 (137G/C and 607C/A) gene polymorphisms and risk of ischemic stroke: A meta-analysis. Neuroreport 2019, 30, 89-94. [CrossRef]

19. Yuepeng, J.; Zhao, X.; Zhao, Y.; Li, L. Gene polymorphism associated with TNF- $\alpha$ (G308A) IL-6 (C174G) and susceptibility to coronary atherosclerotic heart disease: A meta-analysis. Medicine 2019, 98, e13813. [CrossRef]

20. MA3RS Study Investigators. Aortic wall inflammation predicts abdominal aortic aneurysm expansion, rupture, and need for surgical repair. Circulation 2017, 136, 787-797. [CrossRef] 
21. Scola, L.; Di Maggio, F.M.; Vaccarino, L.; Bova, M.; Forte, G.I.; Pisano, C.; Candore, G.; Colonna-Romano, G.; Lio, D.; Ruvolo, G.; et al. Role of TGF- $\beta$ pathway polymorphisms in sporadic thoracic aortic aneurysm: Rs 900 TGF- $\beta 2$ is a marker of differential gender susceptibility. Mediat. Inflamm. 2014, 2014, 165758. [CrossRef]

22. Pisano, C.; Ruvolo, G. Risk of aortic dissection in patients with ascending aorta aneurysm: A new biological, morphological, and biomechanical network behind the aortic diameter. Vessel Plus 2020, 4, 33. [CrossRef]

23. Buffa, S.; Borzì, D.; Chiarelli, R.; Crapanzano, F.; Lena, A.M.; Nania, M.; Candi, E.; Triolo, F.; Ruvolo, G.; Melino, G.; et al. Biomarkers for vascular ageing in aorta tissues and blood samples. Exp. Gerontol. 2019, 128, 110741. [CrossRef]

24. Fujita, D.; Preiss, L.; Aizawa, K.; Asch, F.; Eagle, K.; Suzuki, T. GenTAC registry investigators. Circulating interleukin-6 (IL-6) levels are associated with aortic dimensions in genetic aortic conditions. PLoS ONE 2019, 14, e0214084. [CrossRef]

25. Zhang, L.; Liao, M.F.; Tian, L.; Zou, S.L.; Lu, Q.S.; Bao, J.M.; Pei, Y.F.; Jing, Z.P. Overexpression of interleukin-1 $\beta$ and interferon- $\gamma$ in type I thoracic aortic dissections and ascending thoracic aortic aneurysms: Possible correlation with matrix metalloproteinase-9 expression and apoptosis of aortic media cells. Eur. J. Cardiothorac. Surg. 2011, 40, 17-22. [CrossRef]

26. Kapelski, P.; Skibinska, M.; Maciukiewicz, M.; Pawlak, J.; Dmitrzak-Weglarz, M.; Szczepankiewicz, A.; Zaremba, D.; TwarowskaHauser, J. An association between functional polymorphisms of the interleukin 1 gene complex and schizophrenia using transmission disequilibrium test. Arch. Immunol. Ther. Exp. 2016, 64, 161-168. [CrossRef] [PubMed]

27. Montoya-Ruiz, C.; Jaimes, F.A.; Rugeles, M.T.; López, J.Á.; Bedoya, G.; Velilla, P.A. Variants in LTA, TNF, IL1B and IL10 genes associated with the clinical course of sepsis. Immunol. Res. 2016, 64, 1168-1178. [CrossRef]

28. Jiménez-Sousa, M.Á.; Medrano, L.M.; Liu, P.; Almansa, R.; Fernández-Rodríguez, A.; Gómez-Sánchez, E.; Rico, L.; HerediaRodríguez, M.; Gómez-Pesquera, E.; Tamayo, E.; et al. IL-1B rs16944 polymorphism is related to septic shock and death. Eur. J. Clin. Investig. 2017, 47, 53-62. [CrossRef] [PubMed]

29. Hoseini, F.; Mahmazi, S.; Mahmoodi, K.; Jafari, G.A.; Soltanpour, M.S. Evaluation of the role of -137G/C single nucleotide polymorphism (rs187238) and gene expression levels of the IL-18 in patients with coronary artery disease. Oman Med. J. 2018, 33, 118-125. [CrossRef] [PubMed]

30. Szkup, M.; Chełmecka, E.; Lubkowska, A.; Owczarek, A.J.; Grochans, E. The influence of the TNF $\alpha$ rs1800629 polymorphism on some inflammatory biomarkers in 45-60-year-old women with metabolic syndrome. Aging 2018, 10, 2935-2943. [CrossRef]

31. Ruvolo, G.; Pisano, C.; Candore, G.; Lio, D.; Palmeri, C.; Maresi, E.; Balistreri, C.R. Can the TLR-4-mediated signaling pathway be "a key inflammatory promoter for sporadic TAA"? Mediat. Inflamm. 2014, 2014, 349476. [CrossRef]

32. Balistreri, C.R.; Buffa, S.; Allegra, A.; Pisano, C.; Ruvolo, G.; Colonna-Romano, G.; Lio, D.; Mazzesi, G.; Schiavon, S.; Greco, E.; et al. A typical immune T/B subset profile characterizes bicuspid aortic valve: In an old status? Oxid. Med. Cell. Longev. 2018, 2018, 5879281. [CrossRef]

33. Balistreri, C.R.; Marullo, A.G.M.; Madonna, M.; Cavarretta, E.; Allegra, A.; Cesarini, V.; Iaccarino, A.; Schiavon, S.; Peruzzi, M.; Greco, E.; et al. Deregulation of TLR4 signaling pathway characterizes Bicuspid Aortic valve syndrome. Sci. Rep. 2019, 9, 11028. [CrossRef]

34. Balistreri, C.R.; Crapanzano, F.; Schirone, L.; Allegra, A.; Pisano, C.; Ruvolo, G.; Forte, M.; Greco, E.; Cavarretta, E.; Marullo, A.G.M.; et al. Deregulation of Notch1 pathway and circulating endothelial progenitor cell (EPC) number in patients with bicuspid aortic valve with and without ascending aorta aneurysm. Sci. Rep. 2018, 8, 13834. [CrossRef]

35. Halushka, M.K.; Angelini, A.; Bartoloni, G.; Basso, C.; Batoroeva, L.; Bruneval, P.; Buja, L.M.; Butany, J.; d’Amati, G.; Fallon, J.T.; et al. Consensus statement on surgical pathology of the aorta from the society for cardiovascular pathology and the association for European cardiovascular pathology: II. Noninflammatory degenerative diseases-nomenclature and diagnostic criteria. Cardiovasc. Pathol. 2016, 25, 247-257. [CrossRef]

36. Balistreri, C.R.; Pisano, C.; Martorana, A.; Triolo, O.F.; Lio, D.; Candore, G.; Ruvolo, G. Are the leukocyte telomere length attrition and telomerase activity alteration potential predictor biomarkers for sporadic TAA in aged individuals? Age 2014, 36, 9700. [CrossRef] [PubMed]

37. Wilson, W.R.; Herbert, K.E.; Mistry, Y.; Stevens, S.E.; Patel, H.R.; Hastings, R.A.; Thompson, M.M.; Williams, B. Blood leucocyte telomere DNA content predicts vascular telomere DNA content in humans with and without vascular disease. Eur. Heart J. 2008, 29, 2689-2694. [CrossRef] [PubMed]

38. Tanaka, T.; Narazaki, M.; Kishimoto, T. IL-6 in inflammation, immunity, and disease. Cold Spring Harb. Perspect. Biol. 2014, 6, a016295. [CrossRef]

39. Balistreri, C.R.; Candore, G.; Accardi, G.; Colonna-Romano, G.; Lio, D. NF-кB pathway activators as potential ageing biomarkers: Targets for new therapeutic strategies. Immun. Ageing 2013, 10, 24. [CrossRef] [PubMed]

40. Jenny, N.S.; Tracy, R.P.; Ogg, M.S.; Luong le, A.; Kuller, L.H.; Arnold, A.M.; Sharrett, A.R.; Humphries, S.E. In the elderly, interleukin-6 plasma levels and the $-174 \mathrm{G}>\mathrm{C}$ polymorphism are associated with the development of cardiovascular disease. Arterioscler. Thromb. Vasc. Biol. 2002, 22, 2066-2071. [CrossRef]

41. Jabir, N.R.; Firoz, C.K.; Kamal, M.A.; Damanhouri, G.A.; Alama, M.N.; Alzahrani, A.S.; Almehdar, H.A.; Tabrez, S. Assessment of genetic diversity in IL-6 and RANTES promoters and their level in Saudi coronary artery disease patients. J. Clin. Lab. Anal. 2017, 31, e22092. [CrossRef]

42. Kokje, V.B.C.; Gäbel, G.; Koole, D.; Northoff, B.H.; Holdt, L.M.; Hamming, J.F.; Lindeman, J.H.N. IL-6: A Janus-like factor in abdominal aortic aneurysm disease. Atherosclerosis 2016, 251, 139-146. [CrossRef] 
43. Nishihara, M.; Aoki, H.; Ohno, S.; Furusho, A.; Hirakata, S.; Nishida, N.; Ito, S.; Hayashi, M.; Imaizumi, T.; Fukumoto, Y. The role of IL-6 in pathogenesis of abdominal aortic aneurysm in mice. PLoS ONE 2017, 12, e0185923. [CrossRef]

44. Libra, M.; Signorelli, S.S.; Bevelacqua, Y.; Navolanic, P.M.; Bevelacqua, V.; Polesel, J.; Talamini, R.; Stivala, F.; Mazzarino, M.C.; Malaponte, G. Analysis of G(-174)C IL-6 polymorphism and plasma concentrations of inflammatory markers in patients with type 2 diabetes and peripheral arterial disease. J. Clin. Pathol. 2006, 59, 211-215. [CrossRef] [PubMed]

45. Wick, G.; Backovic, A.; Rabensteiner, E.; Plank, N.; Schwentner, C.; Sgonc, R. The immunology of fibrosis: Innate and adaptive responses. Trends Immunol. 2010, 31, 110-119. [CrossRef] [PubMed]

46. Pawlak, M.; Ho, A.W.; Kuchroo, V.K. Cytokines and transcription factors in the differentiation of CD4+ T helper cell subsets and induction of tissue inflammation and autoimmunity. Curr. Opin. Immunol. 2020, 67, 57-67. [CrossRef] [PubMed]

47. Hu, X.; Wu, T.; Wang, C.; Li, J.; Ying, C. CD248+CD8+ T lymphocytes suppress pathological vascular remodeling in human thoracic aortic aneurysms. Exp. Biol. Med. 2021, 246, 121-129. [CrossRef]

48. Murphy, K.M.; Stockinger, B. Effector T cell plasticity: Flexibility in the face of changing circumstances. Nat. Immunol. 2010, 11, 674-680. [CrossRef] [PubMed]

49. Mensà, E.; Latini, S.; Ramini, D.; Storci, G.; Bonafè, M.; Olivieri, F. The telomere world and aging: Analytical challenges and future perspectives. Ageing Res. Rev. 2019, 50, 27-42. [CrossRef] [PubMed]

50. Aschacher, T.; Salameh, O.; Enzmann, F.; Messne, B.; Bergmann, M. Telomere biology and thoracic aortic aneurysm. Int. J. Mol. Sci. 2017, 19, 3. [CrossRef]

51. Balistreri, C.R.; Pisano, C.; Bertoldo, F.; Massoud, R.; Dolci, S.; Ruvolo, G. Red blood cell distribution width, vascular aging biomarkers, and endothelial progenitor cells for predicting vascular aging and diagnosing/prognosing age-related degenerative arterial diseases. Rejuvenation Res. 2019, 22, 399-408. [CrossRef] [PubMed]

52. Burroughs, V.J.; Maxey, R.W.; Levy, R.A. Racial and ethnic differences in response to medicines: Towards individualized pharmaceutical treatment. J. Natl. Med. Assoc. 2002, 94, 1-26. [PubMed]

53. Hunt, L.M.; Truesdell, N.D.; Kreiner, M.J. Genes, race, and culture in clinical care: Racial profiling in the management of chronic illness. Med. Anthropol. Q. 2013, 27, 253-271. [CrossRef] [PubMed]

54. Byeon, Y.J.J.; Sellers, S.L.; Bonham, V.L. Intersectionality and clinical decision making: The role of race. Am. J. Bioeth. 2019, 19, 20-22. [CrossRef]

55. McAllister, K.; Mechanic, L.E.; Amos, C.; Aschard, H.; Blair, I.A.; Chatterjee, N.; Conti, D.; Gauderman, W.J.; Hsu, L.; Hutter, C.M.; et al. Current challenges and new opportunities for gene-environment interaction studies of complex diseases. Am. J. Epidemiol. 2017, 186, 753-761. [CrossRef] [PubMed] 